\title{
Asset Structure Impact on Capital Structure of Capital Market-Listed Firms in Indonesia and Malaysia
}

\section{Zainal Abidin Sahabuddin}

Department of Defense Economics Faculty of Defense Management Indonesia Defense University Kompleks IPSC, Sentul, Bogor, 16810, Indonesia

\begin{tabular}{|c|c|}
\hline \multirow[b]{2}{*}{$\begin{array}{l}\text { Keywords: Agency } \\
\text { Theory; Asset } \\
\text { Structure; Capital } \\
\text { Structure }\end{array}$} & ABSTRACT \\
\hline & $\begin{array}{l}\text { Debt was able to be used by firm as source of funds for investment-related activities, } \\
\text { especially when the amount of retained earnings was not sufficient to cover the amount } \\
\text { of investment needed. Naturally, the use of debt definitely caused the agency conflict } \\
\text { between firm shareholders and debt holders. To reduce this conflict, the existence of fixed } \\
\text { assets as collateral was needed when firm decided to borrow money from debt holders. }\end{array}$ \\
\hline \multirow[t]{2}{*}{$\begin{array}{l}\text { JEL Classification: } \\
\text { G31, G32 }\end{array}$} & $\begin{array}{l}\text { The purpose of this study was to prove the agency theory perspective by testing an impact } \\
\text { of asset structure on capital structure of firms. The population of this study was the firms } \\
\text { listed on Indonesia Stock Exchange and Malaysian Stock Exchange. The firms as sample } \\
\text { were taken from the population by conducting stratified random sampling method. The } \\
\text { pooled data regression model was used as the data analysis method. This result of this } \\
\text { study showed that asset structure had the positive impact on capital structure. It meant } \\
\text { the causal relationship between asset structure and capital structure happened and was } \\
\text { supported by the agency theory perspective. }\end{array}$ \\
\hline & ABSTRAK \\
\hline $\begin{array}{l}\text { Kata Kunci: } \\
\text { Teori Agensi; } \\
\text { Struktur Aktiva; } \\
\text { Struktur Modal }\end{array}$ & $\begin{array}{l}\text { Pinjaman dapat digunakan oleh sebuah perusahaan sebagai sumber dana untuk membiayai } \\
\text { kegiatan-kegiatan yang berkaitan dengan investasi, terutama ketika laba ditahan tidak lagi } \\
\text { mencukupi kebutuhan untuk investasi. Penggunaan pinjaman tentu saja menyebabkan konflik } \\
\text { agensi antara pemegang saham dengan kreditur atau pemegang utang. Untuk mengurangi konflik } \\
\text { agensi ini, keberadaan aset tetap sebagai barang jaminan diperlukan ketika perusahaan memutuskan } \\
\text { untuk meminjam uang dari kreditur.Tujuan penelitian ini yaitu untuk membuktikan berlakunya } \\
\text { perspektif teori agensi dengan menguji pengaruh struktur aktiva terhadap struktur modal } \\
\text { perusahaan. Populasi yang digunakan dalam penelitian ini yaitu perusahaan-perusahaan yang } \\
\text { tercatat di Bursa Efek Indonesia dan Bursa Malaysia. Perusahaan-perusahaan yang digunakan } \\
\text { sebagai sampel diambil dari populasinya dengan menggunakan metode stratifikasi random. } \\
\text { Penelitian ini menggunakan model regresi data gabungan sebagai metode analisis data. Hasil } \\
\text { penelitian ini menunjukkan bahwa strukturaktiva berpengaruh positifterhadap struktur modal. } \\
\text { Hal ini berarti hubungan kausalitas antara struktur aktiva dan struktur modal terjadi dan didukung } \\
\text { oleh perspektif teori agensi. }\end{array}$ \\
\hline
\end{tabular}


Capital structure is the combination of long-term sources of funds used by the firm (Siegel \& Shim, 1987). Long-term sources of funds can be separated into 2 primary sources, debt and equity. In financial leverage context, both debt and equity have a fixed cost. The first fixed cost is the cost of debt and the second one is the cost of equity. Interest is the cost of debt paid for creditors and preferred stock dividend is the cost of equity paid for stockholders. The existence of these 2 fixed costs will increase available earnings for common shareholders as long as the increase in earnings before interest and taxes happens (Gitman \& Zutter, 2012).

Firm managers are a representative of shareholders (Jensen, 1986). To increase their wealth, shareholders are able to compel the managers to implement the risky projects at the expense of creditors (Easterbrook, 1984). If the risky projects are successful to be done, shareholders will get the amount of profits tending to increase. This condition will make creditors get loss because their fixed interest income is not impacted by the increase in profits resulted from the successful firm projects (Hanafi, 2002). If the risky projects are failed, the creditors will handle all the consequences (Harris \& Raviv, 1991).

Rajan \& Zingales (1995) explain that the existence of collateral asset will decrease the risk of creditors from agency cost of debt. Therefore, the increase in tangible asset proportion as collateral asset will make willingness of creditor improve to supply loan to the firm. The study of Susilawati et al. (2012), Zare et al. (2013), and Sutrisno (2016) supports the explanation of Rajan and Zingales. Actually, the previous studies related to the impact of asset structure on capital structure show not only the positive impact, but also a negative impact (see study of Akbar \& Buttho, 2012; Chechet et al., 2013; Acaravci, 2015; Hamidah, 2016; Trinh \& Phuong, 2016) and an insignificant impact (Vãtavu, 2012 and Sakinah \& Anggono, 2014).
The inconsistency results of these previous studies on this impact indicate that agency theory is not always supported. This becomes the main reason of why this research is done. This research is conducted with some modifications that are different from other studies. Firstly, this study uses the firms listed on capital market coming from 2 countries, i.e. Indonesia and Malaysia. Using the firms listed on 2 capital markets is inspired by study of Mahmud (2003). In his study, Mahmud (2003) uses the firms listed on the stock exchange in 3 countries, Japan, Malaysia, and Pakistan. Although Mahmud (2003) uses fixed asset ratio as one of determinants of capital structure in his model, his study does not focus on proving the agency theory perspective specifically. Instead, his research focuses on how economic growth impacts on capital structure.

Secondly, this study uses the agency theory as the main theory to explain causal relationship between asset structure and capital structure and treats asset growth and firm size as control variable to keep the positive estimation sign of the impact of asset structure on capital available.

\section{HYPOTHESES DEVELOPMENT}

\section{Asset Structure and Capital Structure}

The agency theory perspective proposed by Jensen \& Meckling (1976) states there are 2 types of agency cost, agency cost of outside equity and agency cost of debt. When manager is the owner of the firm, he makes operating decisions to maximize his utility. Agency cost of outside equity happens when manager is not the owner anymore. When manager ownership decreases in the firms, he tends to use the firm resources for his own privileges. Agency costs of debt occur when firm uses debt. These costs include 3 things. Firstly, the opportunity wealth loss caused by the impact of debt on the investment decision. Secondly, the monitoring and bonding expenditure by bondholders and firms. Finally, bankruptcy and reorganization costs. 


\section{Jurnal Keuangan dan Perbankan | KEUANGAN}

Vol. 21, No. 3, Juli 2017: 376-386

Rajan \& Zingales (1995) explain that the existence of collateral assets tends to reduce the risk of creditors from agency cost of debt. The increase in fixed asset proportion as collateral asset will increase the enthusiasm of creditors to offer their money to the firm. This explanation is supported by study of Susilawati et al. (2012), Zare et al. (2013), and Sutrisno (2016) showing asset structure has a positive impact on capital structure. Study of Susilawati based on this mentioned information, the first hypotheses can be formulated as follows.

$\mathrm{H}_{1}$ : Asset structure has the positive impact on capital structure.

\section{Firm Size and Capital Structure}

Static trade-off theory states that a large firm has a tendency to own the diversified risks and less susceptible to bankruptcy so that large firms will own the higher amount of debt (Titman \& Wessels, 1988). This theory is confirmed by previous researchers such as Kartini \& Arianto (2008), Akbar \& Bhutto (2012), Susilawati et al. (2012), Vãtavu (2012), and Zare et al. (2013). Their study shows that firm size has a positive impact on capital structure. Based on this mentioned information, the second hypotheses can be formulated as follows.

$\mathrm{H}_{2}$ : Firm size has the positive impact on capital structure.

\section{Firm Growth and Capital Structure}

To finance their growth, Mahmud (2003) states the pecking order theory gives the solution to the firms about how they begin to realize this idea. According to this theory explained by Brealey et al. (2006), firms tend to use internal financing first. After that, if external financing is required, firms are able to issue debt that may be followed by convertible bonds. Finally, they issue new stock. In other word, this theory states that if the growth in asset is high, firms have to use the debt as their first choice of financing it after using retained earnings as their internal financing. The study of Mahmud (2003), Kartini \& Arianto (2008), and Akbar \& Bhutto (2012) confirm this theory by showing that firm growth has a positive impact on capital structure. Based on this mentioned information, the third hypotheses can be formulated as follows.

$\mathrm{H}_{3}$ : Firm growth has the positive impact on capital structure.

\section{METHODS}

The type of this research is causal. According to Zikmund et al. (2010), the causal research has the aim at identifying cause-and-effect relationship.

Variable is defined by Zikmund et al. (2010) as the empirical assessment of a concept. In this

Table 1. Definition of Variable Operationalization

\begin{tabular}{ll}
\hline \multicolumn{1}{c}{ Variable } & \multicolumn{1}{c}{ Description } \\
\hline Asset structure & $\begin{array}{l}\text { Asset structure is measured by the amount of fixed assets divided by the amount of total assets } \\
\text { at the end of the year. The symbol for asset structure in the regression model is FATAR. } \\
\text { Firm size }\end{array}$ \\
$\begin{array}{l}\text { Firm size is measured by natural logarithm of the amount of total assets at the end of the year. } \\
\text { The symbol for firm size in the regression model is LN_TA. } \\
\text { Firm growth }\end{array}$ & $\begin{array}{l}\text { Firm growth is measured by the growth of total asset at the end of the year. The symbol for firm } \\
\text { growth in the regression model is A_GROWTH. }\end{array}$ \\
\hline
\end{tabular}




\section{Asset Structure Impact on Capital Structure of Capital Market-Listed Firms in Indonesia and Malaysia \\ Zainal Abidin Sahabuddin}

Table 2. The Determination of the Number of Sample Representing the Number of Working Population Based on Stratified Random Sampling

\begin{tabular}{lccc}
\hline \multicolumn{1}{c}{$\begin{array}{c}\text { The Name of } \\
\text { Stock Exchange }\end{array}$} & $\begin{array}{c}\text { The Number of } \\
\text { Working Population }(\mathbf{N})\end{array}$ & $\begin{array}{c}\text { \% } \\
\text { (Percent) }\end{array}$ & $\begin{array}{c}\text { The Number of } \\
\text { Sample (N) }\end{array}$ \\
\hline Indonesia Stock Exchange & 25 & 58.14 & $17.44 \approx 17$ (rounded) \\
Bursa Malaysia & 18 & 41.86 & $12.56 \approx 13$ (rounded) \\
\hline Total & 43 & 100 & 30 \\
\hline
\end{tabular}

research, 2 type variables are available. The first variable is dependent variable and the second one is independent variable. Capital structure acts as dependent variable. On the other hand, asset structure and firm size as well as firm growth become independent variable. The measurement of each variable used can be seen in Table 1 .

The population in the research is Indonesia Stock Exchange and Bursa Malaysia listed firms that are classified into the fiftieth largest market capitalization in 2008-2011. After knowing population used, the next step is determining the sampling frame. According to Zikmund et al. (2010), sampling frame is a list of the elements from which the members of sample may be taken. It is also called the working population because these units will eventually provide units involved in analysis.

The firms becoming the sampling frame follow the required conditions: (1) the firms have to be classified into non-financial firms; (2) the firms have to own the positive value of earnings before interest and taxes. Based on the sampling frame requirements, the number of firms used is 25 firms coming from Indonesia Stock Exchange and 18 firms coming from Bursa Malaysia. By considering this condition, the stratified sampling method is used as the sampling method.

The number of sample is determined by using Slovin formula with 10 percent margin of error (see Suliyanto, 2009). Based on this formula, the number sample representing the population of 50 firms is 30 firms (rounded). Furthermore, 34 firms as the total sample are allocated based on the available percentage number in column of percent. Therefore, the number of sample consists of 17 firms coming from Indonesia Stock Exchange and 17 firms coming from Bursa Malaysia. 17 firms coming from Indonesia Stock Exchange and Bursa Malaysia are taken randomly using random number. The determination of the number of sample representing the working population number can be seen in Table 2 .

The names of firms that are randomly taken as sample can be seen in Table 3. This table has 2 panels, Panel A and Panel B. Panel A shows the names of firms listed on Indonesia Stock Exchange. Panel B shows the names of firms listed on Bursa Malaysia. Firm symbol used refers to the available quote at finance.yahoo.com.

Table 3. The Chosen Names of Firms as Research Sample

\begin{tabular}{cl}
\hline \multicolumn{2}{c}{ Panel A. The names of firms Listed on Indonesia Stock } \\
Exchange
\end{tabular}




\begin{tabular}{ll}
\hline \multicolumn{2}{c}{ Panel B. The Names of Firms Listed on Bursa Malaysia } \\
\hline \multicolumn{1}{c}{ Firm Symbol } & \multicolumn{1}{c}{ The Name of the Firm } \\
\hline 2658.KL & Ajinomoto Malaysia Berhad \\
2674.KL & Alumunium Co. of Malaysia Berhad \\
2219.KL & Asiatic Development Berhad \\
2313.KL & The Ayer Molek Rubber Company Berhad \\
1473.KL & Bandar Raya Development Berhad \\
1899.KL & Batu Kawan Berhad \\
4219.KL & Berjaya Land Berhad \\
1562.KL & Berjaya Sports Toto Berhad \\
2771.KL & Boustead Holdings Berhad \\
4162.KL & British American Tobbaco Malaysia \\
2828.KL & C.I. Holdings Berhad \\
2836.KL & Carlsberg Brewery Malaysia Berhad \\
1929.KL & Chin Teck Plantations Berhad \\
\hline
\end{tabular}

In this research, the archival method is used as the data collection method. Hartono (2012) explains this method is used to get the secondary data. The secondary data used in this research are taken from annual financial report downloaded at www.idx.co.id and www.bursamalaysia.com.

This study employs pooled data regression model as the data analysis method. According to Nachrowi \& Usman (2006), pooled data means combining cross-section with time-series data. After that, the data combination is used to estimate regression model by using ordinary least square as the estimation method. In addition, the regression model can be seen in the first equation as follows.

$$
\begin{aligned}
& \text { LTDER }_{\text {it }}=a_{0}+a_{1} \cdot \text { FATAR }_{\text {it }}+\mathrm{a}_{2} \cdot \text { LN_TA }_{\text {it }}+ \\
& \mathrm{a}_{3} \text {.A_GROWTH } \mathrm{it}_{\mathrm{it}}+\mathrm{e}_{\mathrm{it}}
\end{aligned}
$$

Before testing the regression coefficients $\left(a_{1}\right.$, a2, and a3), the several tests of the classical assumptions are essential to be done first. Because of the estimation method, the regression must fulfill the tests of classical assumption. The tests of the classical assumptions consist of normality test, multicollinearity test, heteroscedasticity test, and autocorrelation test.

\section{Normality test}

Gujarati (2003) explains that normality test is used to ensure that the residuals of regression model follow the normal distribution. In this research, Jarque-Bera (JB) test is conducted as normality test. Null hypothesis states that the residuals are normally distributed whereas alternative hypothesis states that residuals are not normally distributed. Null hypothesis is accepted when probability value of JB statistic is greater than or equal to significance level $(\alpha)$. On the other hand, null hypothesis is rejected when probability value of JB statistic is less than $\alpha$. The significance level used is 5 percent.

\section{Multicollinearity test}

Multicollinearity is the condition where the exact or approximately exact linear relationship among independent variables exists (Gujarati, 2003). This condition is not expected to happen (Kinnear \& Gray, 2009) in good regression model (Ghozali, 2011). To detect it, variance inflation factor (VIF) can be used. Thecut-off value of VIF is 10 (Ghozali, 2011). If VIF value of independent variables used in the model is less than or equal to 10, multicollinearity does not exist. On the contrary, if VIF value exceeds 10, multicollinearity exists in the model.

\section{Heteroscedasticity test}

This test intends to test independency of the explanatory variables towards variance of error. Ghozali (2011) explains that a good regression model does not have heteroscedasticity. We use White test as heteroscedasticity test. This test is done by forming the first following regression equation: 


\section{Asset Structure Impact on Capital Structure of Capital Market-Listed Firms in Indonesia and Malaysia}

Zainal Abidin Sahabuddin

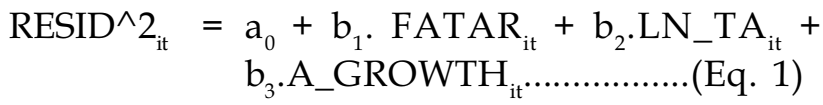

Based on this test, null hypothesis proposed is that all explanatory variables used do not have a causal relationship with variance of error (RESID ${ }^{\wedge} 2$ ). On the other hand, alternative hypothesis proposed is at least there is one independent variable having the causal relationship with variance of error.

E-views Program provides Chi-Square probability value of obs* $\mathrm{R}$-square to test the presence of heteroscedasticity (Widarjono, 2013). Therefore, next step is testing the hypothesis. Null hypothesis is accepted when Chi-Square probability value of obs*R-square is greater than or equal to significance level $(\alpha)$. On the other hand, null hypothesis is rejected when probability value of obs* $R$ square is less than a. The level used is 5 percent.

\section{Autocorrelation test}

This test aims to test the existence of correlation between current residual with previous current residual. If correlation of 2 residuals happens, autocorrelation is available in the regression model, and vice versa. Autocorrelation is undesired condition. To test autocorrelation, we use BreuschGodfrey (BG) Serial Correlation LM test.

Based on this test, null hypothesis proposed is that residuals of current period are not impacted by residuals of previous period (autocorrelation does not exist in the model) whereas alternative hypothesis proposed is that residuals of the current periodare impacted by residuals of previous period (autocorrelation exists in the model). This test is done by forming the second following regression equation:

$$
\begin{aligned}
\operatorname{RESID}_{\mathrm{it}}= & \mathrm{b}_{0}+\mathrm{b}_{1} \cdot \text { FATAR }_{\mathrm{it}}+\mathrm{b}_{2} \cdot \mathrm{LN}_{-} \mathrm{TA}_{\mathrm{it}}+\mathrm{b}_{3} \cdot \mathrm{A}_{-} \\
& \text {GROWTH } \left._{\mathrm{it}}+\mathrm{b}_{4} \cdot \operatorname{RESID}(-1)_{\mathrm{it}} \ldots \ldots \ldots \ldots \text { (Eq. } 2\right)
\end{aligned}
$$

E-Views program provides Chi-Square probability value of obs* R-square to test the presence of autocorrelation (Widarjono, 2013). Therefore, the next step is testing the hypothesis. Null hypothesis is accepted when Chi-Square probability value of obs*R-square is greater than or equal to significance level $(\alpha)$. On the other hand, null hypothesis is rejected when probability value of obs*R-square is less than á. The level of significance used is 5 percent.

\section{Hypotheses Testing Procedure}

The test of the first, the second, and the third hypothesis is conducted by comparing the probability value of $t$-statistic for regression coefficient of FATAR, LN_TA, and A_GROWTH with significance level $(\alpha)$. The significance level used is 10 percent. Therefore, if the probability value of $\mathrm{t}$-statistic of regression coefficient is less than á, alternative hypothesis is accepted whereas if the probability value of regression coefficient is the same as or greater than $\alpha$, null hypothesis is accepted. The use of 10 percent significance level refers to Hartono (2012) stating that the highest value of significance level to reject the null hypothesis is 10 percent.

\section{RESULTS}

Indonesia and Malaysia have a similar condition in ownership structure. A concentrated ownership structure on the controlling shareholders happens in firms in Indonesia (Mutamimah \& Hartono, 2010) and Malaysia (Amran \& Ahmad, 2013). Commonly, controlling shareholders in Malaysia are state, family, and individual (Amran \& Ahmad, 2013). In Indonesia, controlling shareholders are family or founder having a immense control managers to make a decision (Mutamimah \& Hartono, 2010). In this structure, controlling shareholders have a power to push managers to use debt at cost at creditors by asking manager 


\section{Jurnal Keuangan dan Perbankan | KEUANGAN}

Vol. 21, No. 3, Juli 2017: 376-386

for doing investment at risky projects (see Easterbrook, 1984). To give the assurance that a firm does not intends to make creditors become loss if projects of firm are failed, firm gives its collateral assets to creditors. In other word, in line with (Rajan \& Zingales, 1995), the collateral asset will reduce the risk of agency cost of debt.

The following section is the result of classical assumption tests. These tests are essential to do because the regression model using ordinary least square as the estimation method is used as the method of data analysis.

\section{The Result of Normality Test}

Table 4 shows the result of normality test by using Jarque-Bera (JB). In this table, the probability of JB is 0,255262 . This value is greater than 5 percent significance level. Because of this condition, the null hypothesis stating residuals are normally distributed is accepted.

Table 4. Normality Test Result

\begin{tabular}{lr}
\hline \multicolumn{1}{c}{ Description } & Residuals \\
\hline Number of Observation & 120 \\
Jarque-Bera (JB) statistic & 2,730931 \\
Probability of JB & 0,255262 \\
\hline
\end{tabular}

Source: Output of EViews Program

\section{The Result of Multicollinearity Test}

Table 5 shows the detection of multicollinearity. In this table, the value of VIF for each independent variable used is 1.333, 1.347, and 1.018 , respectively. Because all values of VIF are less than 10, multicollinearity does not exist in this regression model.

Table 5. Multicollinearity Detection

\begin{tabular}{lcc}
\hline \multicolumn{1}{c}{ Independent Variable } & Tolerance & VIF \\
\hline FATAR & 0,750 & 1,333 \\
LN_TA & 0,742 & 1,347 \\
A_GROWTH & 0,983 & 1,018 \\
\hline
\end{tabular}

Source: Output of IBM-SPSS Program

\section{The Result of Heteroscedasticiy Test}

Table 6 shows heteroscedasticity test result by using White test. In this table, Chi-Square probability value of $\mathrm{Obs}^{*} \mathrm{R}$-squared is 0.0071 . This value is less than 5 percent significance level. It means alternative hypothesis stating variance of residual is affected by at least one independent variable is accepted. This condition is also confirm by probability value of $\mathrm{LN}_{-} \mathrm{TA}^{\wedge} 2$ that is less than 5 percent. In other word, the presence of heteroscedasticty in this model is caused by LN_TA^ 2 .

Table 6. Heteroscedasticity Test Result

\begin{tabular}{|c|c|c|c|c|}
\hline $\begin{array}{l}\text { F-statistic } \\
\text { Obs*R-squared } \\
\text { Scaled explained SS }\end{array}$ & $\begin{array}{l}4,33 \\
12,0 \\
9,21\end{array}$ & $\begin{array}{l}\text { b. F( }(3,116) \\
\text { b. Chi-Squa } \\
\text { b. Chi-Squa }\end{array}$ & & $\begin{array}{l}0,0062 \\
0,0071 \\
0,0266\end{array}$ \\
\hline \multicolumn{5}{|c|}{$\begin{array}{l}\text { Test Equation: } \\
\text { Dependent Variable: RESID^2 } \\
\text { Method: Least Squares } \\
\text { Date: 02/01/17 Time: } 14: 19 \\
\text { Included observations: } 120\end{array}$} \\
\hline Variable & Coefficient & Std. Error & t-Statistic & Prob. \\
\hline $\mathrm{C}$ & $-0,300663$ & 0,173960 & $-1,728340$ & 0,0866 \\
\hline $\mathrm{FATAR}^{\wedge} 2$ & 0,050233 & 0,040255 & 1,247872 & 0,2146 \\
\hline LN_TA^2 & 0,004108 & 0,001918 & 2,141586 & 0,0343 \\
\hline A_GROWTH^${ }^{\wedge} 2$ & $-0,027104$ & 0,072780 & $-0,372404$ & 0,7103 \\
\hline
\end{tabular}

Source: Output of E-Views Program 


\section{Asset Structure Impact on Capital Structure of Capital Market-Listed Firms in Indonesia and Malaysia \\ Zainal Abidin Sahabuddin}

\section{The Result of Autocorrelation Test}

Table 7 shows autocorrelation test result by using BG Serial Correlation LM test. In this table, Chi-Square probability value of Obs* $\mathrm{R}$-squared is 0.0000 . This value is less than 5 percent significance level. It means alternative hypothesis stating residuals of current periodare affected by residuals of previous period is accepted. This condition is also confirmed by probability value of $\operatorname{RESID}(-1)$ that is less than 5 percent.

\section{The Regression Model Estimation}

Based on Table 6 dan Table 7, heteroscedasticity and autocorrelation still exist in regression model. Widarjono (2013) states the use of Newey, Whitney, and Kenneth method can overcome these 2 problems. This method makes the standard error still consistent although 2 problems occur simultaneously. E-Views program is able to make the regression model estimation under this condition. Table 8 is output of E-views program show-

Table 7. Autocorrelation Test Result Breusch-Godfrey Serial Correlation LM

\begin{tabular}{lll}
\hline \hline F-statistic & 57,43255 Prob. $F(1,115)$ & 0,0000 \\
Obs*R-squared & 39,96871 Prob. Chi-Square $(1)$ & 0,0000 \\
\hline \hline
\end{tabular}

Test Equation:

Dependent Variable: RESID

Method: Least Squares

Date: 02/01/17 Time: 14:40

Sample: 1120

Presample and interior missing value lagged residuals set to zero.

\begin{tabular}{lccrc}
\hline \hline \multicolumn{1}{c}{ Variable } & Coefficient & Std. Error & t-Statistic & Prob. \\
\hline \hline C & $-0,268417$ & 0,685558 & $-0,391531$ & 0,6961 \\
FATAR & $-0,054969$ & 0,120144 & $-0,457527$ & 0,6482 \\
LN_TA & 0,037472 & 0,074359 & 0,503927 & 0,6153 \\
A_GROWTH & $-0,152521$ & 0,152767 & $-0,998390$ & 0,3202 \\
RESID(-1) & 0,609668 & 0,080448 & 7,578426 & 0,0000 \\
\hline \hline
\end{tabular}

Source: Output of E-Views Program

Table 8. Estimation of Regression Model: The Impact of Asset Structure on Capital Structure and Firm Size and Firm Growth as Control Variable

Dependent Variable: LTDER

Method: Least Squares

Date: 02/01/17 Time: 14:36

Sample: 1120

Newey-West HAC Standard Errors \& Covariance (lag truncation=4)

\begin{tabular}{|c|c|c|c|c|}
\hline Variable & Coefficient & Std. Error & t-Statistic & Prob. \\
\hline $\mathrm{C}$ & $-4,711492$ & 1,429738 & $-3,295354$ & 0,0013 \\
\hline FATAR & 0,450873 & 0,268249 & 1,680797 & 0,0955 \\
\hline LN_TA & 0,534918 & 0,155332 & 3,443718 & 0,0008 \\
\hline A_GROWTH & 0,358621 & 0,185992 & 1,928147 & 0,0563 \\
\hline
\end{tabular}

Source: Output of E-Views Program 


\section{Jurnal Keuangan dan Perbankan | KEUANGAN}

Vol. 21, No. 3, Juli 2017: 376-386

ing the method of Newey-West Heteroscedasticity and Autocorrelation Consistent (HAC) Standard Errors \& Covariance. Therefore, the test of 4 hypotheses refer to this table.

\section{Hypotheses Testing Result}

The first hypothesis states that asset structure has a positive impact on capital structure. This positive impact is tested by comparing the probability value of $\mathrm{t}$-statistic for FATAR coefficient with 10 percent significance level. In Table 8 , probability value of $t$-statistic for FATAR is 0,0955 . Because this probability value of $t$-statistic for FATAR coefficient is less than 10 percent, the first hypothesis is accepted.

The second hypothesis states that firm size has a positive impact on capital structure. This positive impact is tested by comparing the probability value of LN_TA coefficient with 10 percent significance level. In Table 8 , probability value of t-statistic for LN_TA is 0,0008 . Because this probability value of $\mathrm{t}$-statistic for FATAR coefficient is less than 10 percent, the second hypothesis is accepted.

The third hypothesis states that firm growth has a positive impact on capital structure. This positive impact is tested by comparing the probability value of $t$-statistic for A_GROWTH coefficient with 10 percent significance level. In Table 8, probability value of $\mathrm{t}$-statistic for A_GROWTH is 0.0563 . Because this probability value of A_GROWTH coefficient is less than 10 percent, the third hypothesis is accepted.

\section{DISCUSSION}

In this study, the asset structure as the main variable is proven to have a positive impact on capital structure. Therefore, this study confirms Rajan \& Zingales (1995) and the previous study conducted by Susilawati et al. (2012), Zare et al. (2013), and Sutrisno (2016). This result indicates asset structure is strongly associated with capital structure. By providing collateral assets, a firm directly gives attention to protecting its creditors or debt holders from potential failure of investment the firm conducts. If the firm is not able to fulfill its obligation to its creditors, the creditors have a power to force the firm to sell its collateral assets according to debt contract that they sign together.

As the control variable, firm size and growth have significantly impact on capital structure. Both firm size and firm growth have a positive impact on capital structure. The positive impact of firm size on capital structure confirms argument of static trade-off theory stated by Titman \& Wessels (1988) and previous study conducted by Kartini \& Arianto (2008), Akbar \& Bhutto (2012), Vãtavu (2012), and Zare et al. (2013). This evidence indicates the big firms are able to diversify some risks because they can hire the professional staff to manage their business-related risks such as strategic risk, financial risk, operational risk, and compilant risk. Naturally, the purpose of hiring the staff is to make a firm survive.

The positive impact of firm growth on capital structure confirms argument of pecking order theory used by Mahmud (2003) to test the positive impact of firm growth on capital structure and the study of Mahmud (2003), Kartini \& Arianto, (2008), and Akbar \& Bhutto (2012). This evidence indicates firm growth is considered as important variable for firms to arrange capital stucture. In expansion context, the growing firms have to use debts to finance their investment in expansion because their retained earnings are not sufficient. Obviously, this thing is done to make them keep available (Kartini \& Arianto, 2008).

\section{CONCLUSION AND SUGGESTIONS}

\section{Conclusion}

The aim of this study is to prove the existence of agency theory on the causal relationship between asset structure and capital structure ar- 


\section{Asset Structure Impact on Capital Structure of Capital Market-Listed Firms in Indonesia and Malaysia}

Zainal Abidin Sahabuddin

ranged by the firms on Indonesia Stock Exchange and Bursa Malaysia. This study is successful to prove the agency theory by showing a positive impact of asset structure on capital structure. The evidence means providing collateral assets is able to give an assurance to creditors both in Indonesia and Malaysia about the willingness of firm to pay for debts. Obviously, a firm does not want to lose its valuable assets becoming collateral. Therefore, the firm will attempt to get them back by paying for an interest and principal continuously.

\section{Suggestions}

This study has some following limitations. Firstly, it only uses firms coming from 2 capital markets from 2 different countries. Based on this limitation, the next researchers are able to use firms coming from more than 2 capital markets and treat the country where capital market acts as dummy variable. Furthermore, this dummy variable can be tested as moderating variable by using the interaction effect or subgroup analysis to develop the existing theory. This action is the suggestion for a science development. Secondly, this study only uses 4 years as the number of the time period observation. This time period is too short. Based on this limitation, next researchers can extend the observation of the time period into 10 years or 15 years to make their research more meaningful in capturing the manager behavior to make a decision of capital structure.

Besides the recommendations given to next researchers to overcome the limitations of this study, this study also gives the recommendation for firms and creditors. Firms are suggested providing collateral assets when they want to get the money from bank or capital market to get a trust from creditors. This study suggests that creditors lend their money to firms without doubt and conduct loose monitoring activities on firms.

\section{REFERENCES}

Acaravci, S.K. 2015. The Determinants of Capital Structure: Evidence from the Turkish Manufacturing Sector. International Journal of Economics and Financial Issues, 5(1): 158-171.

Amran, N.A. \& Ahmad, A.C. 2013. Effects of Ownership Structure on Malaysian Companies Performance. Asian Journal of Accounting and Governance, 4: 5160.

Akbar, U.S. \& Bhutto, N.A. 2012. Determinants and Policies of Capital Structure in the Non-Financial Firms (Personal Care Goods) of Pakistan. Asian Journal of Business and Management Sciences, 2(2): 27-35.

Brealey, R.A., Myers, S.C., \& Allen, F. 2006. Corporate Finance. Eight Edition. Singapore: McGrawHill.

Chechet, I.L., Garba, S.L., \& Odudu, A.S. 2013. Determinant of Capital Structure in the Nigerian Chemi$\mathrm{cal}$ and Paint Sector. International Journal of $\mathrm{Hu}$ manities and Social Science, 3(15): 247-263.

Easterbrook, F.H. 1984. Two Agency-Cost Explanations of Dividends. The American Economic Review, 74(4): 650-659.

Gitman, L.J. \& Zutter, C.J. 2012. Principles of Managerial Finance. $13^{\text {th }}$ Edition. Boston: Prentice-Hall.

Gujarati, D.N. 2003. Basic Econometrics. Fourth Edition. Singapore: McGraw-Hill Education.

Hamidah, 2016. Analysis of Factors Affecting the Capital Structure and Profitability in Indonesian's Manufacturing Company Year 2009-2013. Jurnal Keuangan dan Perbankan, 20(2): 157-165.

Hanafi, M.M. 2002. Manajemen Keuangan. Edisi 2004/ 2005. Yogyakarta: BPFE-UGM.

Harris, M. \& Raviv, A. 1991. The Theory of Capital Structure. The Journal of Finance, 46(1): 297-355.

Hartono, J. 2012. Metodologi Penelitian Bisnis: Salah Kaprah dan Pengalaman-Pengalaman. Yogyakarta: BPFEUGM.

Jensen, M.C. \& Meckling, W.H. 1976. Theory of the Firm: Managerial Behavior, Agency Costs, and Ownership Structure. Journal of Financial Economics, 3(4): 305-360. 


\section{Jurnal Keuangan dan Perbankan | KEUANGAN}

Vol. 21, No. 3, Juli 2017: 376-386

Jensen, M.C. 1986. Agency Cost of Free Cash Flow, Corporate Finance, and Takeover. The American Economic Review, 76(2): 323-329.

Kartini \& Arianto, T. 2008. Struktur Kepemilikan, Profitabilitas, Pertumbuhan Aktiva, dan Ukuran Perusahaan terhadap Struktur Modal pada Perusahaan Manufaktur. Jurnal Keuangan dan Perbankan, 12(1): 11-21.

Kinnear, P.R. \& Gray, C.D. 2009. SPSS 16 Made Simple. New York: Psychology Press.

Mahmud, M. 2003. The Relationship between Economic Growth and Capital Stucture of Listed Companies: Evidence of Japan, Malaysia, and Pakistan. The Pakistan Development Review, 42(4): 727-750.

Mutamimah \& Hartono, S. 2010. Dividend, Debt, and Investment Policies as Corporate Governance Mechanism. Business Perspective, 7(2).

Nachrowi, N.D. \& Usman, H. 2006. Pendekatan Populer dan Praktis Ekonometrika untuk Analisis Ekonomi dan Keuangan. Jakarta: Lembaga Penerbit Fakultas Ekonomi Universitas Indonesia.

Rajan, R.G. \& Zingales, L. 1995. What Do We Know about Capital Structure? Some Evidence from International Data. The Journal of Finance, 50(5): 1421-1460.

Sakinah, A.N. \& Anggono, A.H. 2014. Analysis of Determinants of Capital Structure of Plantation Companies in Indonesia. Journal of Business and Management, 3(1): 21-32.

Siegel, J.G. \& Shim, J.K. 1987. Kamus Istilah Akuntansi. Jakarta: PT Elex Media Komputindo.
Suliyanto. 2009. Metode Riset Bisnis. Yogyakarta: Andi.

Susilawati, C.D.K., Agustina, L., Tin, S. 2012. FaktorFaktor yang Memengaruhi Kebijakan Utang Perusahaan Manufaktur yang Terdaftar di Bursa Efek Indonesia. Jurnal Keuangan dan Perbankan, 16(2): 178-187.

Sutrisno. 2016. Capital Structure Determinants and Their Impact on Firm Value: Evidence from Indonesia. Economics World, 4(4): 179-186.

Titman, S. \& Wessels, R. 1988. The Determinants of Capital Structure Choice. The Journal of Finance, 43(1): 119.

Trinh, T.H. \& Phuong, N.T. 2016. Effects of Financial Crisis on Capital Structure of Listed Firms in Vietnam. International Journal of Financial Research, 7(1): 66-74.

Vãtavu, S. 2012. Determinants of Capital Structure: Evidence from Romanian Manufacturing Companies. Advanced Research in Scientific Areas, 1(1): 670-673.

Widarjono, A. 2013. Ekonometrika: Pengantar dan Aplikasinya Disertai Panduan Eviews. Edisi Keempat. Yogyakarta: UPP STIM YKPN.

Zare, R., Farzanfar, F., \& Boroumand, M. 2013. Examining the Firm Age, Size, and Asset Structure Effects on Financial Leverage in the Firms Listed in Tehran Stock Exchange. International Journal of Economy, Management, and Social Sciences, 2(6): 256-264.

Zikmund, W.G., Babin, B.J., Carr, J.C., \& Griffin, M. 2010. Business Research Methods. Eight Edition. Canada: South-Western Cengange Learning. 